\title{
DENSITY, STEADY AND DYNAMIC STATE SHEAR RHEOLOGICAL PROPERTIES OF GONGURA (HIBISCUS SABDARIFFA) LEAVE PUREE AS A FUNCTION OF TEMPERATURE \& TSS
}

\author{
J. Meher ${ }^{1 *}$, A. Keshav ${ }^{1}$, B.Mazumdar ${ }^{1}$ \\ ${ }^{1}$ Food Research and Intensification Lab, Department of Agricultural Engineering, Kalasalingam University \\ *jaga@klu.ac.in \\ https://doi.org/10.34302/2019.11.4.7

\begin{tabular}{l} 
Article history: \\
Received: \\
$\quad 17$ February 2019 \\
Accepted: \\
$\quad 10$ October 2019 \\
\hline Keywords: \\
Gongura Leaves; \\
Density; \\
Puree; \\
Rheology; \\
TSS.
\end{tabular}

\begin{abstract}
Rheological properties must be assessed for the processing and handling of different pastes and purees. Cox Merz rule was applied and variation in dynamic and steady-state properties with temperature (283-358K) was evaluated for Gongura leaves puree. Mathematical models were applied in relation to experimentally obtain TSS and density and it was concluded that the linear correlation was best suited. With an increment in TSS and decrement in temperature, there is an increment in the density of the puree. HB model was found to be best fitted and described the flow behavior of the puree, within the temperature range $\left(\mathrm{R}^{2}>0.98\right)$. In the frequency range $(1-50 \mathrm{~Hz})$, the product shows weak gel behavior. Modified Cox Merz rule can be useful where it was revealed that the steady-state viscosity is
\end{abstract} \\ identical to complex viscosity raised to power $\alpha$.
}

\section{Introduction}

Gongura leaf (GL) is a species of hibiscus, utilized as a part of many dishes in Sri Lanka, India, and neighboring nations. Besides, in the vast majority of the nations, it is called 'Roselle'. The young leaves are eaten raw in salads and crushed or chopped with the tender stem as chutney. It is added to curries as flavor enhancer after fried along with the chopped onion in the first stage of preparation and in some Malaysian dishes as a seasoning. Medically it is used for the treatment of different chronic diseases in Ayurvedic medicines (Puro et al., 2014). It is a natural remedy for cancer, blood pressure, and anemia as it is a very good source of folic acid and iron and improves the digestive system, as it is carminative in nature. Amongst the different chutney available in south India, the most widely consumed chutney in breakfast is the GL based chutney, which is prepared by blending the leaves using blender processor until the preferred consistency reached.

Fresh GL is perishable in nature and has a short time frame of shelf life, and the quality of the leaves deteriorates due to microbial and physiological behavior during the period of storage and transportation. In addition, the dried form of leaves has a poor (inferior) aroma and hence widely not suited to use in a different food product. Hence, there is a need for minimally processing of the fresh leaves into puree to preserve and maintain the quality of food with freshness. These food items are in the form of puree when processed, handled, stored and sold. These are easily consumable and remain fresh until consumed by the customer. As people are lean towards the ready to use a form of products, so it can also save time and money. A pureed form of chutney can be used for topping, seasoning and has recipes for the fast-food industry(Espinosa,2011). A puree is a suspension of soft particles in viscous gel or 
serum and is obtained from fruit/vegetable by processes like heat treatment and tissue restructuration (Colin Henrion et al 2007).

Physical properties of foods like viscoelasticity and density are the key parameters utilized as a part of the designing, evaluation, and optimization of processing parameters. In addition, the physical properties are quality indices of food (Alvarado and Romero, 1989., Pourmohammadi et al., 2017). This information is used for the emergent of the latest food items without having the most wanted qualities or for quality enhancement of previously present products. Also, for defining the effectiveness of food systems if designing information are accessible. The density of GL puree is extremely influenced by both TSS (total soluble solid) \& temperature. Therefore, it becomes necessary to obtain the physical property values of GL puree as a function of temperature and TSS (Hajieghrary \& Homayouni-Rad (2016)). Previously different authors have worked on the consequence of temperature and soluble solid concentration on its density of different fruits (Constenla et al., 1989) and developed some Empirical equations that linked the density of TSS \& temperature. A wide range of temperature was chosen as our puree experienced different processing conditions with a change in viscosity. Along with varying temperature and concentration, the shear rate of the puree also has a greater impact on its processing operation like pipe flow, pumping, stirring and mixing. The viscosities of the puree were measured at temperatures between 283 to $358 \mathrm{~K}$. Since this is the range of temperature that the fluid products experienced during the evaporation study (Nindo, 2004). In low acid foods $(\mathrm{pH}<4.5)$, the main purpose is the destruction of pathogenic bacteria, while below $\mathrm{pH} 4.5$ the destruction of spoilage microorganisms or enzyme deactivation is usually more important. Also, Past research work by the researcher on the impact of $\mathrm{pH}$ on the viscosity of sweet potato puree and quince puree demonstrated that the consistency of puree increase with $\mathrm{pH}$ value (Ice et al., 1980). However, very few works have been done on the processed form of vegetables with varying temperatures, TSS and pHs.

Dynamic rheological properties of food can be used for ensuring the total cyclic chain of food processing that started from harvesting to storage (Campo-Deaño and Tovar 2009). The small-amplitude oscillatory shear run is a kind of rheological test in which strain and stress value change with time in the LVR (linear viscoelastic region). It is more imperative to know the viscoelastic properties of purees, which is essential for the food processor for altering planning parameters, checking consistency and the mouthfeel characteristics of prepared food. Hence, dynamic rheology is usually applied to estimate the viscoelastic characteristics of paste/puree. Broad temperature ranges are experienced all through the preparing and storage of pureed foods, and hence, the temperature influence on flow properties must be recorded (Rao 1999). Different worked has done on different viscoelastic food materials such as vegetablebased baby foods(Ahmed and Ramaswamy 2006a), sweet potato-based infant food puree (Ahmed and Ramaswamy, 2006b) and strained pureed baby foods (Ahmed and Ramaswamy 2007a) in the range of temperatures (278$353 \mathrm{~K})$. In view of differentiation in puree composition and distinguishing situations inside the puree, the rheological behavior is very particular in association with one TSS to another. Because of the complicated nature of purees and their change subsidiaries, it is inaccessible for the food preparation industry throughout the food formulation. Henceforth, knowing the rheological characteristics of GL is necessary for assessing its proposed utilization and use as food stabilizers or thickeners. An analysis of the viscoelastic properties of vegetable puree in the LVE region keeps a check on the process. It also helps in maintaining the consistency and stability of liquid and formulated food.

The present work emphasizes on determining a) the density of GL puree and to model the effect of temperature (283-358K) 
and TSSs $\left(4.6^{0}\right.$ Brix $)$ b) the dynamic rheological properties of GL puree in the LVE range by both amplitude sweep and frequency sweep tests and its dependency on TSS $\left(4.6^{\circ}\right.$ Brix $)$ and temperature.

\section{Materials and methods}

The fresh GL was procured from a Kota market, Chhattisgarh, India. Vegetables were cleaned with distilled water. An adequate amount of distilled water was transferred into a container and heated to the desired temperature (363K) for the blanching of vegetable leaves. A desired amount of leaves was sunk in an abundance of water \& then go through blanching, in the separate blanching media for 5 min. Peroxidase inactivity test was performed to know the exact duration and viability of the sample. Immediately after blanching, the leaves are quenched in the cold water to stop the degradation of essential components present in it. Then, the blanched vegetable was ground in a wet grinder (Remi Lab Equipment, India) for a specified amount of time until the puree is formed. The pureed material was then passed through the sieves of $14 \mathrm{~m}$ size, to obtain a puree of uniform consistency. Samples used were obtained from GL, with a TSS of $5.6^{0}$ Brix.

\subsection{Physiochemical analysis}

Chlorophyll content was analyzed using the method described by Arnon (1949). The pH and TSS ( ${ }^{0}$ Brix) of the samples were determined using a handy $\mathrm{pH}$ meter and Otago refractometer (Tokyo, Japan) at 303K, respectively. Samples of 1.6, 2.6, $3.6 \& 4.6^{0}$ Brix were obtained by diluting the concentrated form of puree by using distilled water.

The density of the puree was evaluated by pycnometers of $25 \mathrm{ml}$ measure from 283 to $358 \mathrm{~K}$, at temperatures increment of $15 \mathrm{~K}$. All the pycnometer has been before calibrated with pure water, to check potential contrasts in their volume, by a heating method. The instant measurement was then carried of Pycnometers by an analytical balance (0.0001 g precision). Each experiment was repeated thrice at 283,
$298,313,328,343$ and $358 \mathrm{~K}$ with TSS of 1.6 , 2.6, 3.6, 4.6 and $5.6{ }^{0}$ Brix. Four distinct models, for example, linear, exponential, exponential quadratic \& quadratic are attempted to fits the test data utilizing MS office 2007. The fitting accurateness of computed parameters was estimated through the interpretation of $\mathrm{R}^{2}$ and plot of prediction error with confidence intervals $(p=0.05)$.

\subsection{Rheology procedures}

The rheological analysis of GL puree was performed by means of a modular compact four-bladed vane (ST22-4V-40) rheometer ( MCR 102 (Anton Paar, GmbH, Germany) The vane was dipped into the cylinder and was kept at $10 \mathrm{~mm}$ above from the bottom of the cylinder (Steffe, 1996).

At the required temperature, the concentrated puree $(35 \mathrm{ml})$ was poured into the sample cup (40ml). The sample puree was carefully transferred into the cup so that no air bubble was present. The surplus puree was removing with a spatula. The temperature of the cup \& samples were maintained to equilibrate with the experimental temperatures $(283,298,313,328$, $343 \& 358 \mathrm{~K}$ ) before measuring the rheological parameters. Fresh samples were taken with appropriate care for all testing to stay away from the consequences of the aging \& high shear rate during sample loading.

\subsubsection{Steady-state measurements}

The steady-state shear experiments were conducted in the range between .01-100/s (Steffe, 1996). In order to avoid thixotropy(data not shown), the samples were sheared for 5 minutes at 300/s thixotropy. HerschelBuckley's (HB) model (Eq. 1) was employed to calculate the flow behavior of the purees. HB model embodies power law, Newton \&, Bingham models and used for the explanation of the rheological properties of the food products.

$$
\sigma=\sigma_{0}+K * \gamma^{n}
$$




\subsubsection{Dynamic oscillatory measurements}

The dynamic viscoelastic components of blanched puree $\left(\mathrm{TSS}=3.6^{0} \mathrm{Brix}\right)$ were measured such as loss tangent (tan d), complex viscosity $\left(\mathrm{h}^{*}\right), \quad \mathrm{G}^{\prime}$ (storage modulus), \& G" (loss modulus), at a temperature range of $283-333 \mathrm{~K}$. During each experimentation run, fresh samples were utilized to keep away from the consequence of maturing \& high shear rate throughout sample loading, Both, frequency, \& strain sweep test was performed as previously mentioned temperatures. Strain sweep tests were conducted at a steady frequency of $1 \mathrm{~Hz}$ to decide the limit of the linear viscoelastic regime of the sample (LVR). Frequency sweep tests were done at a steady strain of $0.02 \%$ in the range $(0.01$ to $10 \mathrm{~Hz})$ in the field of LVR at temperatures(283-358K) to defined the mechanical spectra of $\mathrm{G}^{\prime} \& \mathrm{G}^{\prime \prime}(\mathrm{Pa})$ values. Frequency sweep tests at a steady strain in the LVE region were completed to decide the viscoelastic nature of GL puree. The G' can be utilized as a measure of the elastic part of the sample \& correspondingly, the G" describes the viscous portion of the specimen. The information of rheological evaluations was analyzed utilizing the RheoPlus programming of Anton Paar $\mathrm{GmbH}$ for calculation of dynamic rheological properties \& examine the rheological results. Each oscillatory measurement was completed in triplicate. The viscoelastic behavior ( $\left.G^{\prime} \& G^{\prime \prime}\right)$ of food \& dispersions were modeled as a power function of oscillatory frequency (Eqs. 2-3) (Rao, 1999).

$$
\begin{aligned}
& G^{\prime}=G_{0}^{\prime} \omega^{n^{\prime}} \\
& G^{\prime \prime}=G_{0}^{\prime \prime} \omega^{n^{\prime \prime}}
\end{aligned}
$$

Where $G_{0}^{\prime}(\mathrm{Pa}), G_{0}^{\prime \prime}(\mathrm{Pa}), \omega$ and n'\& n" (dimensionless) are the storage modulus, viscous modulus, oscillation frequency, and exponents which denote the influence degree of $\omega$ on both modulus respectively.

\subsubsection{Applicability of the Cox-Merz rule}

According to Cox-Merz rule, at a specific shear rate $(\gamma)$, when $\gamma=\omega$, then the complex viscosity at a particular $\omega$ is equal to $\eta_{a}$ at a specific shear rate (Rao, 2005). The rheological properties of food can be ascertained by steady-state or oscillatory shear experiments; subjected to the validation of Cox-Merz rule (Gunasekaran and Ak, 2000). Both the experiments are adjuvant because of having certain limitations in each kind.

Appraisal of the Cox-Merz rule was assessed by the outcomes got from steady-state shear and viscoelastic investigation.

$\eta_{a}(\gamma)=\left.\eta *(\omega)\right|_{\gamma=\omega}$

\section{Results and discussions}

\subsection{Effects of temperature and TSS on its density of GL puree}

The experimentally obtained results comprising the impact of temperature and TSS on the density of the GL puree were presented in Table 1. It is very much clear from the data that the density of the GL puree increased with increment in TSS and decrement in temperature. Regardless of the temperature scale, the density was observed to be well influenced by the TSS of the puree. For an example case point, at $283 \mathrm{~K}$, density increased from $1.102 \mathrm{~g} / \mathrm{cm}^{3}$ at $1.6{ }^{0}$ Brix to $1.379 \mathrm{~g} / \mathrm{cm}^{3}$ at $5.6^{\circ} \mathrm{Brix}$, which involves an increase of $31.1 \%$ in case of GL puree. Similarly, there are increases in density nearly $25-30 \%$ are observed in other temperature range.

At a fixed TSS of $5.6{ }^{\circ}$ Brix, the density decreased by $1.376 \%$, with an increment of temperature from $283 \mathrm{~K}$ to $358 \mathrm{~K}$. Similar types of results are obtained in case of clear grape juice (Zuritz et al., 2005), whereby it was reported that, with increment in TSS from 22.9 to $70.6{ }^{0}$ Brix at a fixed $353 \mathrm{~K}$, density increment by $24.11 \%$. Density is extremely vital in determining the material handling, packaging requirement and during wet processing of the food sector (Karuna et al., 1996). Various models were used to fit the data with the experimental value of density with temp and concentration of GL puree(Aguado and Ibarz, 1988). These models are quadratic, 
linear, quadratic exponential and exponential as revealed in the Eqs. (5-8):

$$
\begin{aligned}
& \rho=a+b X+c X^{2} \\
& \rho=a+b X \\
& \ln \rho=a+b X+c X^{2} \\
& \ln \rho=a+b X
\end{aligned}
$$

Where $a, b$, and $c$ are constants; $\rho$ is density in $\mathrm{g} / \mathrm{cm}^{3}$; and $\mathrm{X}$ is the variable to model, temperature (K) or TSS $\left({ }^{0}\right.$ Brix) respectively.

For a fixed TSS, density decreases with an increase in temperature (Table 1). Various models (Eqs. 5-8) are used to fit the experimental data. Regression coefficient values range from 0.98 to 0.99 from the regression analysis. Increasing TSS causes an increase in the values of parameter $a \& b$.
However, in the case of quadratic and exponential quadratic models, c values were dismissed as it was discovered unimportant $\left(10^{-6}\right.$ requests). In this way, it may be recommended that a linear model, on account of its appropriate fitting and consistency, may help to find density as a factor of temperature. Concerning the effect of TSS, density change under set temperature increased with the increment of TSS under a relative temperature effect (Table. 2). So, a straight model can be proposed for the GL puree density as a part of TSS. As per previous findings at $25^{\circ} \mathrm{C}$, the density variation of cleared and depectinised juice of Malus floribunda with concentration is observed to be linear (Cepeda and Villarán,

\begin{tabular}{|c|c|c|c|c|c|}
\hline \multirow{2}{*}{$\begin{array}{l}\text { Temperature } \\
\text { (K) }\end{array}$} & \multicolumn{5}{|c|}{ Density $\left(\mathrm{g} / \mathrm{cm}^{3}\right)$} \\
\hline & $1.6^{0} \mathrm{Brix}$ & $2.6^{0} \mathrm{Brix}$ & $3.6^{0}$ Brix & $4.6^{0} \mathrm{Brix}$ & $5.6^{0} \mathrm{Brix}$ \\
\hline 283 & 1.102 & 1.1724 & 1.23984 & 1.30813 & 1.37933 \\
\hline 298 & 1.098 & 1.164858 & 1.233416 & 1.301152 & 1.372576 \\
\hline 313 & 1.09375 & 1.16215 & 1.23129 & 1.29988 & 1.37108 \\
\hline 328 & 1.08975 & 1.156608 & 1.225166 & 1.292902 & 1.363726 \\
\hline 343 & 1.0855 & 1.1539 & 1.22304 & 1.29163 & 1.36213 \\
\hline 358 & 1.0815 & 1.148358 & 1.216916 & 1.284652 & 1.355376 \\
\hline
\end{tabular}
1999).

Table 1. Experimental values for density (in $\mathrm{g} / \mathrm{cm} 3$ ) at different concentrations and temperature for Gongura leaves puree.

Table 2. Fitting parameters for equations to predict the variation of density of Gongura leaves puree with temperature and TSS.

\begin{tabular}{|c|c|c|c|c|c|}
\hline Models & $\mathbf{0}$ Brix & $\mathbf{a}$ & $\mathbf{- b}^{*} \mathbf{1 0}^{\mathbf{4}}$ & $\mathbf{C}^{*} \mathbf{1 0}^{\mathbf{- 6}}$ & $\mathbf{R}^{\mathbf{2}}$ \\
\hline \multirow{4}{*}{$\rho=a+b X$} & 1.6 & 1.1062 & 5 & - & 0.9999 \\
\cline { 2 - 6 } & 2.6 & 1.1756 & 5 & - & 0.9828 \\
\cline { 2 - 6 } & 3.6 & 1.2435 & 4 & - & 0.9825 \\
\cline { 2 - 6 } & 4.6 & 1.3117 & 4 & - & 0.9677 \\
\cline { 2 - 6 } & 5.6 & 1.3832 & 3 & - & 0.9735 \\
\hline \multirow{5}{*}{$\rho=a+b X+c X^{2}$} & 1.6 & 1.1062 & 5 & 0.0000000000003 & 0.9999 \\
\cline { 2 - 6 } & 2.6 & 1.1772 & 6 & 2 & 0.9861 \\
\cline { 2 - 6 } & 3.6 & 1.2437 & 5 & 0.3 & 0.9826 \\
\cline { 2 - 6 } & 4.6 & 1.3117 & 4 & 0.000000000003 & 0.9677 \\
\cline { 2 - 6 } & 5.6 & 1.3831 & 4 & -0.07 & 0.9735 \\
\hline \multirow{5}{*}{$\ln \rho=a+b X$} & 1.6 & 1.1062 & 4 & - & 0.9999 \\
\cline { 2 - 6 } & 2.6 & 1.1755 & 4 & - & 0.9833 \\
\hline
\end{tabular}




\begin{tabular}{|c|c|c|c|c|c|}
\hline \multirow{5}{*}{$\ln \rho=a+b X+c X^{2}$} & 3.6 & 1.2435 & 4 & - & 0.9826 \\
\cline { 2 - 6 } & 4.6 & 1.3118 & 3 & - & 0.9677 \\
\cline { 2 - 6 } & 5.6 & 1.3833 & 3 & - & 0.9734 \\
\hline & 1.6 & 0.1009 & 5 & -0.07 & 0.9999 \\
\cline { 2 - 6 } & 2.6 & 0.1632 & 4 & 1 & 0.9862 \\
\cline { 2 - 6 } & 3.6 & 0.2181 & -0.0004 & 0.0000001 & 0.9826 \\
\cline { 2 - 6 } & 4.6 & 0.2713 & -0.0003 & -0.00000007 & 0.9677 \\
\cline { 2 - 6 } & 5.6 & 0.3244 & -0.0003 & -0.00000007 & 0.9735 \\
\hline
\end{tabular}

\subsection{Rheological studies on purees}

\subsubsection{Steady-state shear properties}

Figure 1, demonstrates the flow curves of shear rate and stress of GL puree at $283-358 \mathrm{~K}$. Obviously, the GL puree demonstrated sheardiminishing conduct $(\mathrm{n}<1)$ with a yield value. The yield stress characterized as slightest shear stress important to start product flow, linked with the breaking of the material's inner structure (Tabilo-Munizaga and BarbosaCánovas, 2005). Elastic deformation happens underneath the yield stress making it act like an elastic solid; however material flows over the yield stress making it act like a viscous liquid(Bayod et al., 2007). If there should arise an occurrence of multiphase material like vegetable puree/paste, which is formed by a dispersion of insoluble parts (materials of cell wall) in a water solution (serum, containing sugars, minerals, proteins, and solvent polysaccharides), is having a yield stress (Sun and Gunasekaran, 2009). Table 3, describes the estimations of the HB model parameters for GL puree in the assessed temperature range. A higher estimation of $\mathrm{R}^{2}$ (more than 0.98 ) was obtained for all cases. A nearby value for yield stress, flow behavior index (n), and consistency coefficient $(\mathrm{k})$ were acquired tentatively when contrasted with values from the literature for vegetable items (Table 4; 283-358K).

High consistency is a typical characteristic of GL as resembled by yield stress (59.245 Pa) and consistency index (35.94746 $\mathrm{Pa} \mathrm{sn}$ ) value at $283 \mathrm{~K}$. With the increase in temperature, there is an increase in flow behavior index, while there is a decrease in yield stress and consistency index. Although the shear thinning behavior reduces with temperature, it is still present at $358 \mathrm{~K}(\mathrm{n}=0.45893)$.In order to model the temperature effect on the rheology of food one must mull over how apparent viscosity changes with temperature. In order to evaluate non-Newtonian fluid, each of the parameters present in Hershey Buckley needs to be modeled individually. Therefore, each of these parameters was modeled as a function of temperature. Arrhenius Equation (Eq. (9) expresses the variation of consistency index (K) with temperature.

$$
\ln K=\left(\frac{E_{a}}{R}\right) * T^{-1}+B
$$

Here, Ea, R, T, and B represent the activation energy $\left(\mathrm{kJ} \cdot \mathrm{mol}^{-1}\right)$, constant of the ideal gases $\left(\mathrm{J} \mathrm{g}^{-1} \mathrm{~mol}^{-1} \mathrm{~K}^{-1}\right)$, absolute temperature $(\mathrm{K})$ and the Arrhenius Constant $\left(\mathrm{Pas}^{\mathrm{n}}\right)$ respectively.

In comparison to other vegetable products (Table 5), the activation energy of GL puree was found to be smaller $\left(\mathrm{Ea}=5.062 \mathrm{KJ} \mathrm{mol}^{-1}\right)$. Thus it can be concluded that in comparison to other vegetable products, the internal structure of GL puree is more affected by temperature. The lower value of the consistency index explained in terms of an increase of Brownian motion with temperature, resulting in the less developed structure at a higher temperature (Massa et al. (2010)).

$\ln K=\left(\frac{5.062}{R}\right) * T^{-1}+0.01$

Rao (1999) showed that the flow behavior index does not vary with temperature but for GL, Figure 2, depicts an increase in flow behavior index with temperature and a linear model can be applied. (Eq. (11); $\mathrm{R}^{2}=0.97$ ): 
$n=0.1874+0.0008 * T$

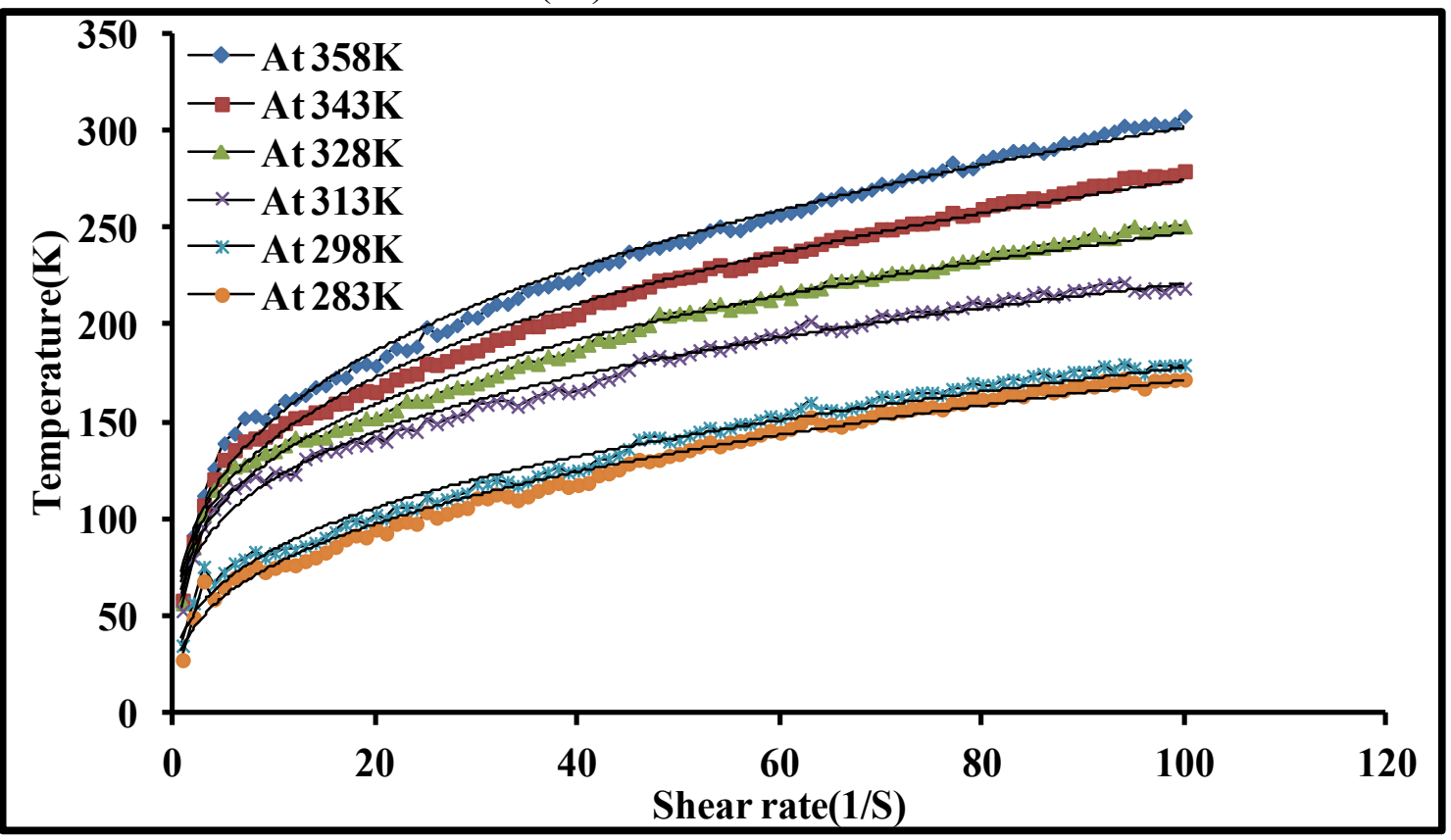

Figure 1. Flow curves of Gongura leave puree $\left(\mathrm{TSS}=4 \cdot 6^{0} \mathrm{Brix}, \mathrm{T}=283-358 \mathrm{~K}\right)$.

Table 3. Values for the parameters of the Herschel-Buckley model for the GL puree

\begin{tabular}{|c|c|c|c|c|}
\hline $\mathbf{T ~ ( K )}$ & $\sigma_{0}(\mathbf{P a})$ & $\mathbf{K}_{(\mathbf{P a ~ s}} \mathbf{)}$ & $\mathbf{n}$ & $\mathbf{R}^{\mathbf{2}}$ \\
\hline $\mathbf{2 8 3}$ & 59.245 & 35.94746 & 0.39898 & 0.987 \\
\hline $\mathbf{2 9 8}$ & 56.987 & 32.50153 & 0.41778 & 0.988 \\
\hline $\mathbf{3 1 3}$ & 55.9874 & 26.32514 & 0.43012 & 0.997 \\
\hline $\mathbf{3 2 8}$ & 49.2896 & 23.30368 & 0.44171 & 0.989 \\
\hline $\mathbf{3 4 3}$ & 24.3214 & 19.23751 & 0.44785 & 0.995 \\
\hline $\mathbf{3 5 8}$ & 16.851 & 17.72813 & 0.45893 & 0.979 \\
\hline
\end{tabular}

Table 4. Values for the parameters of the Herschel-Buckley model for vegetable products.

\begin{tabular}{|c|c|c|c|c|c|}
\hline Product & $\mathbf{T}(\mathrm{K})$ & $\sigma_{0}(\mathrm{~Pa})$ & k $\left(\mathbf{P a} . s^{n}\right)$ & n & References \\
\hline $\begin{array}{l}\text { Sweet potato } \\
\text { puree }\end{array}$ & $278-353$ & $0.54-1.82$ & $0.44-1.52$ & $0.34-0.54$ & $\begin{array}{l}\text { Ahmed and } \\
\text { Ramaswamy(2006) }\end{array}$ \\
\hline $\begin{array}{l}\text { Coriander leaf } \\
\text { puree }\end{array}$ & \multirow[t]{2}{*}{$303-353$} & $10.9-36.1$ & - & $0.455-0.735$ & \multirow[t]{2}{*}{ Rudra et al.(2008) } \\
\hline Mint leaf puree & & $26.0-489.0$ & - & $0.137-0.451$ & \\
\hline Fenugreek paste & $283-303$ & $1.050-3.675$ & $2.351-7.478$ & $0.706-0.834$ & $\begin{array}{l}\text { Işıklı and } \\
\text { Karababa(2005) }\end{array}$ \\
\hline Ginger paste & $298-338$ & $63.3-159.2$ & $29.30-269.88$ & $0.52-0.66$ & Ahmed(2004) \\
\hline $\begin{array}{l}\text { Rocket leave } \\
\text { puree }\end{array}$ & $298-343$ & $2.89-4.26$ & $167-402$ & $0.10-0.22$ & Ahmed et al.(2013) \\
\hline $\begin{array}{l}\text { Vegetable-based } \\
\text { infant puree }\end{array}$ & $278-338$ & $2.08-14.26$ & $13.56-76.09$ & $0.21-0.75$ & $\begin{array}{l}\text { Alvarez et al. } \\
(2013)\end{array}$ \\
\hline $\begin{array}{l}\text { Tamarind juice } \\
\text { concentrates }\end{array}$ & $283-363$ & $0.91-3.88$ & $0.27-9.28$ & $0.43-0.78$ & $\begin{array}{l}\text { Manohar et } \\
\text { al.(1991) }\end{array}$ \\
\hline
\end{tabular}




\begin{tabular}{|l|c|c|c|c|l|}
\hline $\begin{array}{l}\text { Beetroot juice } \\
\text { concentrates }\end{array}$ & $298-328$ & $0.013-0.080$ & $0.008-0.189$ & $0.70-0.99$ & $\begin{array}{l}\text { Kumar and } \\
\text { Kumar(2015) }\end{array}$ \\
\hline $\begin{array}{l}\text { Gongura leaves } \\
\text { puree }\end{array}$ & $283-318$ & $72.41-100.40$ & $11.56-16.04$ & $0.157-0.523$ & Present work \\
\hline
\end{tabular}

Table 5. Activation energy (Ea) of the Arrhenius model $\left(\mathrm{A}=\mathrm{A}_{0} \exp (\mathrm{Ea} / \mathrm{RT})\right)$ for the consistency Index $(\mathrm{K})$ in Vegetable products.

\begin{tabular}{|l|c|l|}
\hline \multicolumn{1}{|c|}{ Product } & Ea (k) $\left.\mathbf{( k J ~ m o l}^{-\mathbf{1}}\right)$ & \multicolumn{1}{c|}{ References } \\
\hline Tomato paste & $8.600-13.000$ & Dak et al. (2008) \\
\hline Curry leaves puree & $16.18-30.14$ & Meher et al. (2017) \\
\hline Jabuticaba pulp & 13.00 & Sato and Cunha (2007) \\
\hline Tomato juice & 7.353 .3 & Augusto et al. \\
\hline Gongura leaves puree & 5.062644 & Present work \\
\hline
\end{tabular}

In the literature, no modeling of yield stress has been carried out as its behavior is not definite. In the case of peach puree $\left(21^{\circ} \mathrm{Brix}\right)$, it remains constant (between 278 and $328 \mathrm{~K}$; Massa et al., 2010), in the case of Butia puree it shows a continuous declining behavior (at 283 and 333K; Haminiuk et al., 2006) while in case of potato puree it shows an unpredictable behavior (298 and 338K; Canet et al., 2005). Here it is important to note that the yield stress depends on the product as well as the temperature range selected.

Even though the shear stress declines with increasing temperature, the Arrhenius equation cannot be utilized to model the behavior. For the tomato juice, yield stress was modeled using Arrhenius Equation (the other works listed in Table 4), however the same cannot be applied for the case of Gongura leaves as the behavior is different.

Figure 2 (c) shows the behavior of yield stress versus temperature as sigmoidal (Eq. (12); $\mathrm{R}^{2}=$ $0.98)$. It can be seen from the graph that the yield stress remains constant $(55.98-59.24 \mathrm{~Pa})$ within the temperature range of $280-313 \mathrm{~K}$. After $313 \mathrm{~K}$, yield stress declines monotonously up to the temperature of $358 \mathrm{~K}$. Beyond $358 \mathrm{~K}$, it again attains a constant value (16.851 Pa). The viscoelastic study confirms this observation (Figure 3). After fitting the experimental data, the sigmoidal equation formulated is expressed in equation (12).

$$
\sigma_{0}=\frac{42.21}{1+e(T-33) / 5.76}+15.97
$$
a)

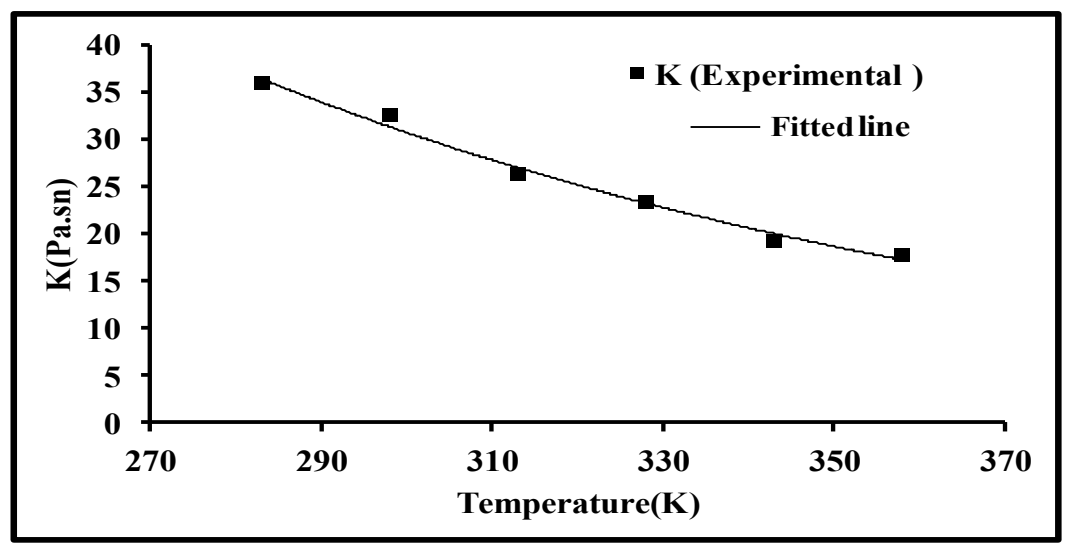


b)

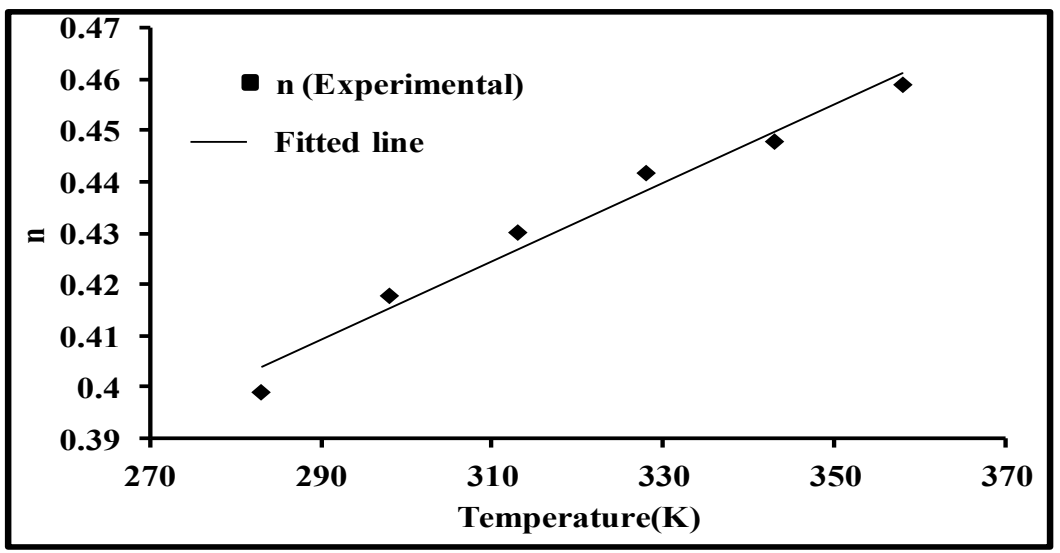

c)

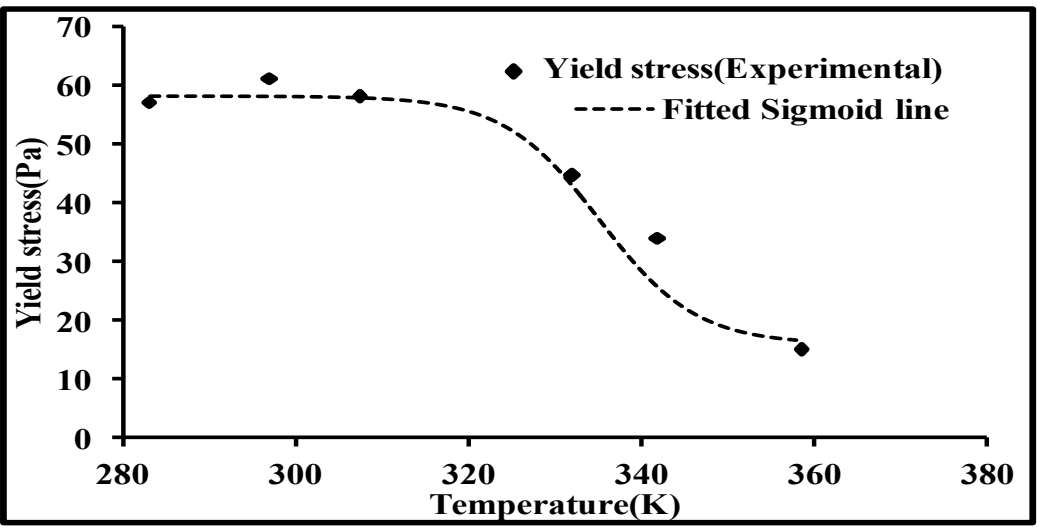

Figure 2 (a-c). Parameters of the Herschel-Bulkley model as a function of temperature.

\subsubsection{Viscoelastic properties}

Figure 3, shows the mechanical spectra of $\mathrm{GL}$ at 283 and $358 \mathrm{~K}$. It can be seen from the graph that the $G^{\prime}$ is higher than the values of G'. Thus, it can be inferred that the elastic behavior supersedes viscous behavior. Hence, the behavior of GL puree is confirmed as a weak gel (Rao, 1999). Parallel findings have been done for other food products such as potato puree (Alvarez et al., 2004), baby foods (Ahmed and Ramaswamy, 2006), tomato concentrates (Bayod et al., 2008) and tomato juice (Augusto et al., in press-b). Apparent and complex viscosity decreases with an increase in shear rate/frequency. It can be seen from figure 5 that $\mathrm{G}$ ' is dominant over G' ' at temperatures $(283 \mathrm{~K}$ and $358 \mathrm{~K})$. Hence, $\mathrm{G}^{\prime}$ and $\mathrm{G}^{\prime \prime}$ were modeled as a power function of oscillatory frequency as shown by Eq. (2-3). The $\mathrm{R}^{2}$ values were found to be greater than 0.93 when the experiments were replicated (thrice).
Experimental values in agreement with literature values were obtained (Table 6). The $n$ " values were always greater than n' (Table 6), which shows that the viscous nature of GL comparatively significant in high frequencies. At high temperatures, the consistency becomes constant, as $K$ ' and $K$ " value converges to a constant value (Table 4, Figure 4). The estimations of $\mathrm{n}^{\prime}$ and $\mathrm{n}^{\prime \prime}$ are consistent with temperature (280-360K), according to reporting (n; Rao, 1999). The mean values for $n^{\prime}$ and $n "$ from Figure 4, are 0.127 and 0.06495 respectively. The $\mathrm{K}^{\prime}$ and $\mathrm{K}^{\prime \prime}$ values exhibit a sigmoidal decay behavior with temperature, for the yield stress. As can be found in Figure 4, both $\mathrm{K}^{\prime}$ and $\mathrm{K}^{\prime \prime}$ demonstrated moderately predictable values in the temperature ( 283$313 \mathrm{~K})$. It shows that the GL viscoelastic properties are a low dependent of temperature at this range, reflecting low inner structure changes. In reality, it is similar conduct 
observed for the yield stress (Figure 2). Again, it is watched that the basic changes in the $\mathrm{K}^{\prime}$ and $\mathrm{K}^{\prime \prime}$ values are done at the temperatures of 313 and $358 \mathrm{~K}$, supporting the yield stress finding. This conduct could be all around demonstrated by a power sigmoidal function (Eqs. (12) and (13); $\left.\mathrm{R}^{2}>0.97\right)$. It is intriguing to watch that, even for $\mathrm{K}^{\prime}$ and $\mathrm{K}^{\prime \prime}$, the parameters identified with the sigmoidal shape are a remarkable same (the proportional and power parameters in temperature). It exhibits that the reduction in the extents of $G^{\prime}$ and $G^{\prime \prime}$ in connection with temperature follows a similar pattern:

$$
k^{\prime}=\frac{1051.8}{1+e(T-315) / 10.4875}+341.809
$$

$$
k^{\prime \prime}=\frac{219.91}{1+e(T-315) / 13.02}+74.42
$$

The watched conduct is not the same as those saw in different products, in spite of the fact that there are only a couple of studies that have demonstrated the estimations of $K^{\prime}, K^{\prime \prime}, n^{\prime}$ and $n^{\prime \prime}$ as an element of temperature. Ahmed et al. (2007) and Ahmed and Ramaswamy (2006) depicted that the temperature impact was not efficient in the assessment of $K^{\prime}, K^{\prime \prime}, n^{\prime}$ and $n^{\prime \prime}$ of baby food (293-353K). Augusto et al. (2011) have shown the estimations of $n^{\prime}$ and $n "$ as a quadratic function (second-order polynomial ) in association with a temperature in peach juices with fibers $(273-313 \mathrm{~K})$. The estimations of $\mathrm{K}^{\prime}$ and $\mathrm{K}^{\prime \prime}$ were shown using the Arrhenius Equation. Emphasize that the property conduct regarding temperature is a function of the product itself and in addition to the investigated temperature range.

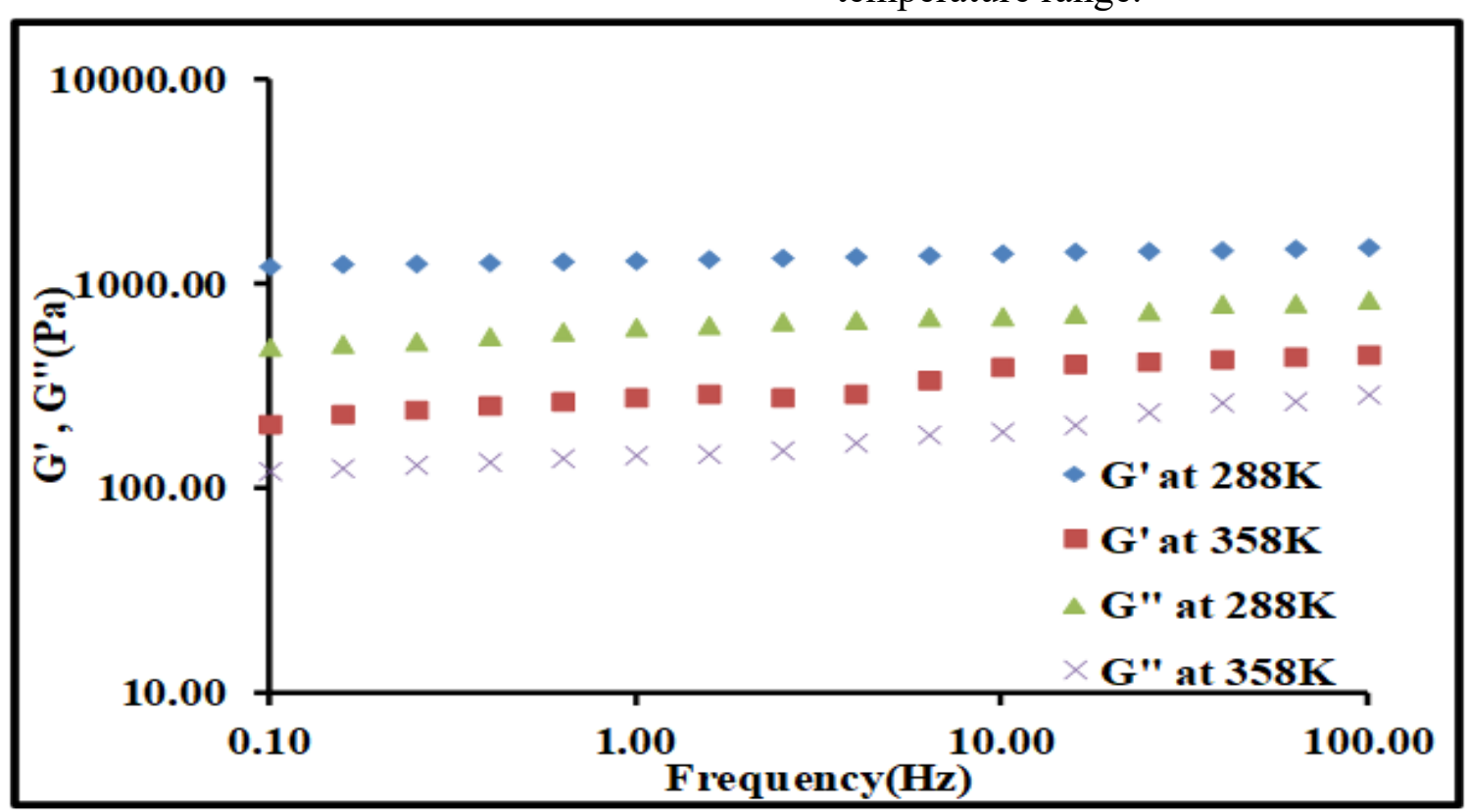

Figure 3. Mechanical spectra of Gongura leave puree at 283 and $358 \mathrm{~K}$.

a) 


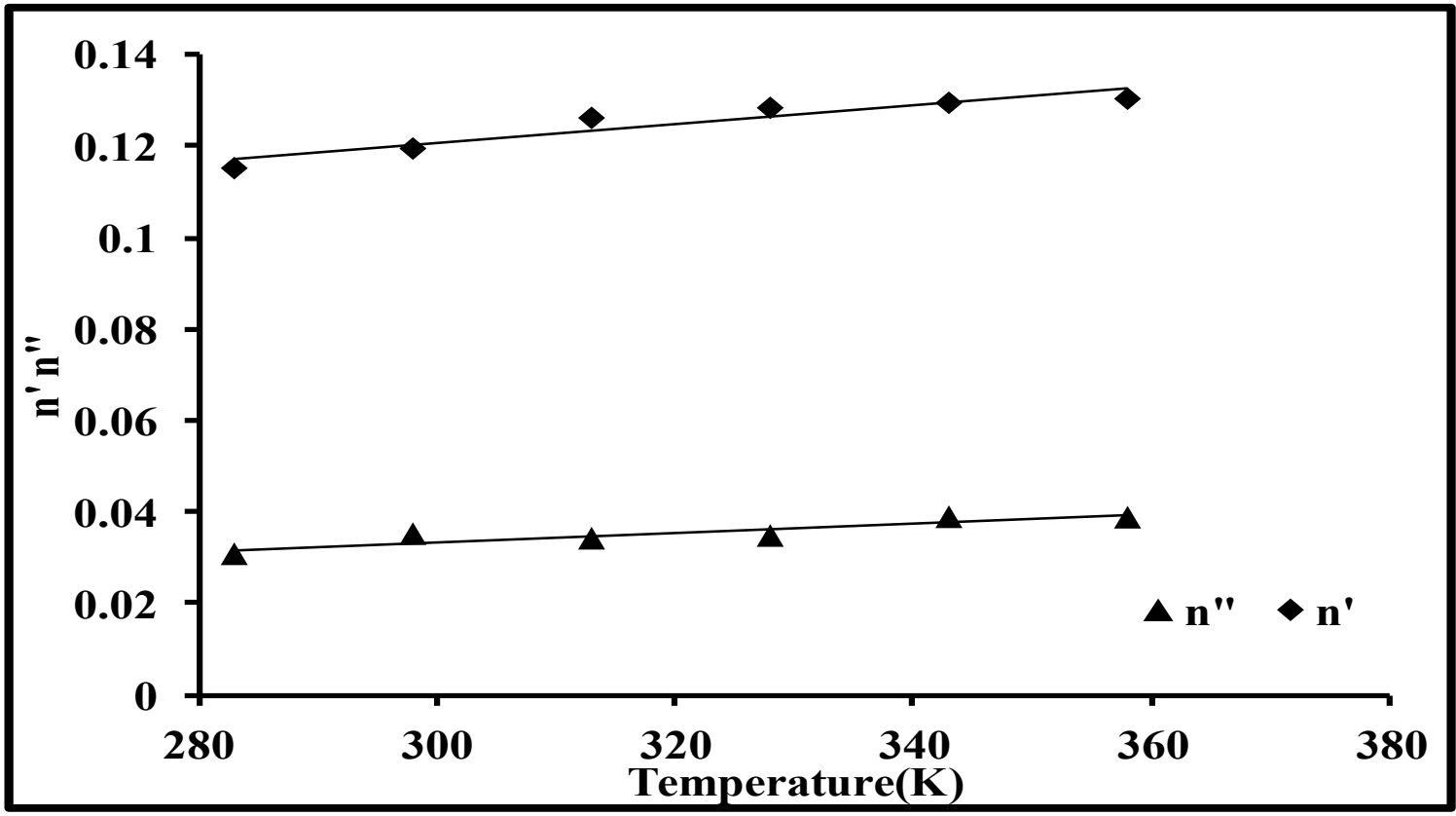

b)

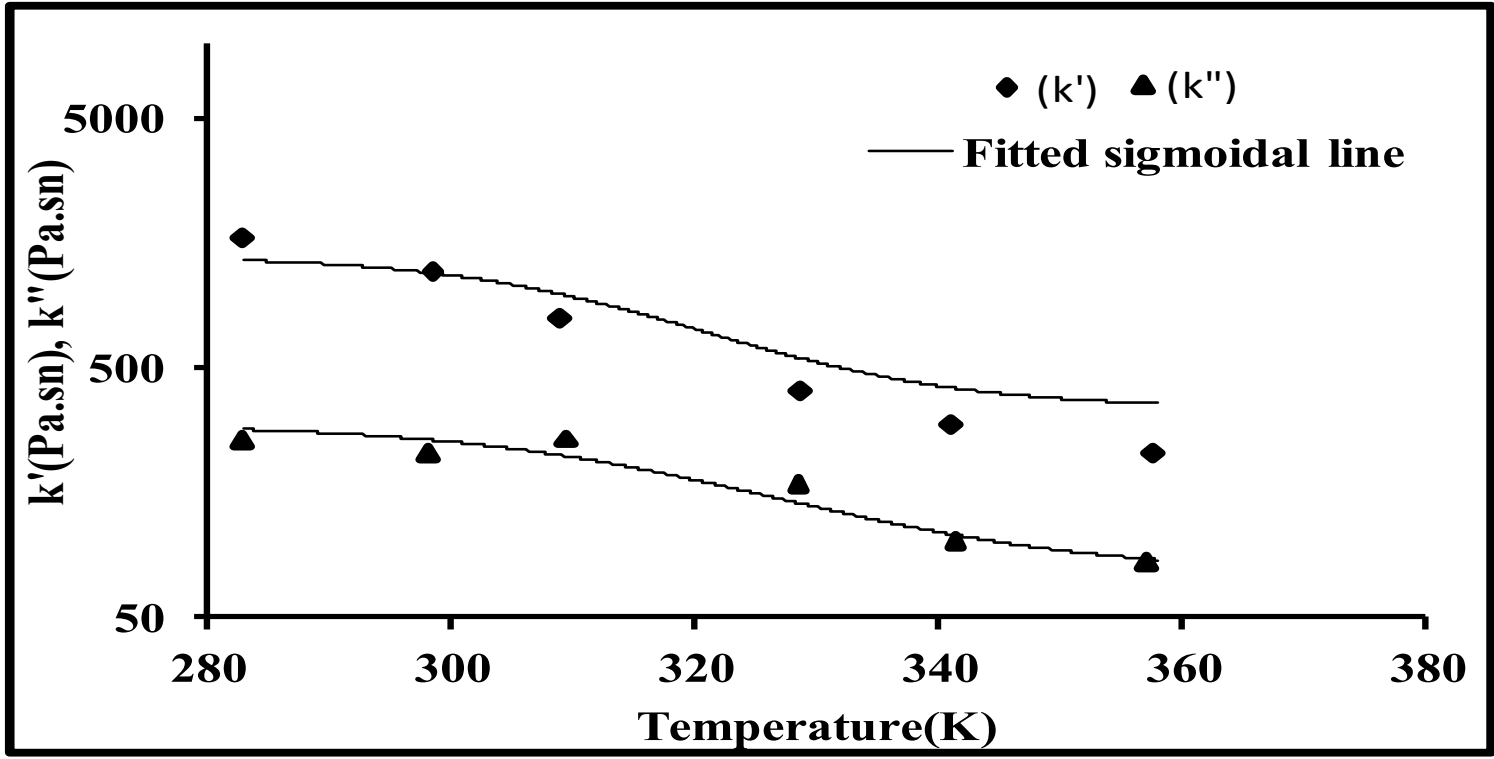

Figure 4(a-b). Temperature dependency of the parameters of the power-law model for storage $\left(\mathrm{G}^{\prime}\right)$ and loss $\left(G^{\prime \prime}\right)$ modules as a function of oscillatory frequency $(\omega)$.

Table 6. Values for the power-law model for storage (G') and loss (G’) modules of GL puree as a function of oscillatory frequency $(\omega)(1 \mathrm{~Pa})$

\begin{tabular}{|c|c|c|c|c|c|c|c|}
\hline \multicolumn{2}{|l|}{ Product } & $\mathbf{T}(\mathrm{K})$ & K'(Pa.sn') & n' & K"(Pa.sn") & n" & References \\
\hline \multicolumn{2}{|c|}{$\begin{array}{l}\text { Vegetable based } \\
\text { baby food }\end{array}$} & $\begin{array}{l}293- \\
298 \mathrm{~K}\end{array}$ & $\begin{array}{l}131.0- \\
13500\end{array}$ & $\begin{array}{l}0.06- \\
0.14\end{array}$ & $\begin{array}{l}19.7- \\
1750\end{array}$ & $\begin{array}{l}0.16- \\
0.22\end{array}$ & $\begin{array}{lr}\text { Ahmed } & \& \\
\text { Ramaswamy(2006) }\end{array}$ \\
\hline \multirow[t]{2}{*}{$\begin{array}{l}\text { Tomato } \\
\text { products }\end{array}$} & Paste & \multirow[t]{2}{*}{$\begin{array}{l}293- \\
298 K\end{array}$} & $\begin{array}{l}9763.3- \\
11607.5\end{array}$ & $\begin{array}{l}0.121- \\
0.139\end{array}$ & $\begin{array}{l}1659.9- \\
2539.0\end{array}$ & $\begin{array}{l}0.2077- \\
0.2546\end{array}$ & \multirow[t]{2}{*}{ Bayod et al. (2008) } \\
\hline & Ketchup & & $\begin{array}{l}560.0- \\
735.5\end{array}$ & $\begin{array}{l}0.102- \\
0.108\end{array}$ & $\begin{array}{l}106.6- \\
159.5\end{array}$ & $\begin{array}{l}0.3032- \\
0.3313\end{array}$ & \\
\hline \multicolumn{2}{|c|}{ Peach juice } & $273-$ & 263.9- & $0.14-$ & $59.8-$ & $0.24-$ & Augusto \\
\hline
\end{tabular}




\begin{tabular}{|l|l|l|l|l|l|l|}
\hline & $313 \mathrm{~K}$ & 1567.1 & 0.28 & 616.6 & 0.54 & $(2011)$ \\
\hline Gongura leaves & $283-$ & $357.37-$ & $0.030-$ & $85.461-$ & $0.0662-$ & Present work \\
puree & $358 \mathrm{~K}$ & 1316.2 & 0.103 & 277.35 & 0.1284 & \\
\hline
\end{tabular}

\subsubsection{Applicability of the Cox-Merz rule}

As per the Cox-Merz rule, when the shear rate is equal to frequency than the steady shear viscosity is almost equivalent to dynamic shear viscosity (Cox and Merz, 1958). Cox- Merz governs is connected to complex food. This experimental model is utilized for relating substantial deformation (the steady shear flow) and the small and linear deformation (Gunasekaran and Ak, 2000). Whether or not Cox-Merz rule can be applied in GL puree (equation (4)) was checked by comparing the plots of apparent viscosity against shear rate and complex viscosity against angular frequency. Modifications in Cox-Merz rule are required when it is to be applied in complex food systems as compared to simple cases of polymeric dispersions where the rule can be applied directly (Rao, 2005). The inapplicability of the Cox-Merz rule for complex dispersions is due to the structural decay caused by the high amount of applied strain(Ahmed and Ramaswamy, 2006), the occurrence of high-density agglomerates(Da Silva and Rao, 1992). Rheological properties of GL puree are very different from polymeric solutions and resemble the properties shown by structured systems (Ahmed and Ramaswamy,
2006). With modifications in the Cox-Merz rule, the oscillatory and steady-state rheological properties can be correlated with complex food. (Rao, 2005). A slight modification has been proposed by Bistany and Kokini (1983) in the actual rule where the original terms have been raised to some power $\alpha$. Table 7 depicts that the R2 was found to be more than 0.96 for the GL puree for the modified Kox-Merz rule.

$\beta \cdot\left[\eta_{a}(\gamma)\right]^{\alpha}=\left.\eta *(\omega)\right|_{\gamma=\omega}$

With reference to other food products (tamarind juice, potato puree, fruit-based baby foods), GL is found to be consistently similar to $\alpha \& \beta$ values (Table 7). In the modified CoxMerz rule, $\alpha$ value corresponds to the behavior difference whereas $\beta$ value resembles the magnitude difference between the complex and the apparent viscosities, It can be inferred from Figure 5, that the $\alpha$ and $\beta$ values are constantly decreasing with temperature. Whereas, no particular trend was found to fit $\alpha$ and $\beta$ values as per the observations of Alvarez et al. (2004). Thus, it can be seen that both oscillatory and steady-state experiments can be used for the determination of the rheological properties of GL puree.

Table 7. Values for the parameters of the modified Cox-Merz rule for Vegetable products

\begin{tabular}{|l|c|c|c|l|}
\hline Products & $\mathbf{T} \mathbf{( K )}$ & $\boldsymbol{\alpha}$ & $\boldsymbol{\beta}$ & $\mathbf{R}^{\mathbf{2}}$ \\
\hline Potato puree & $298-338$ & $0.90-1.35$ & $2.15-39.83$ & Alvarez et al. (2004) \\
\hline Tamarind juice & $283-363$ & $0.67-1.06$ & $0.86-30.82$ & Ahmed et al. (2007) \\
\hline Apple baby food & $278-353$ & $1.15-1.20$ & $4.64-6.99$ & Ahmed et al. (2007) \\
\hline Gongura leaves puree & $283-358$ & $1.05-1.12$ & $2.59-9.84$ & Present work \\
\hline
\end{tabular}




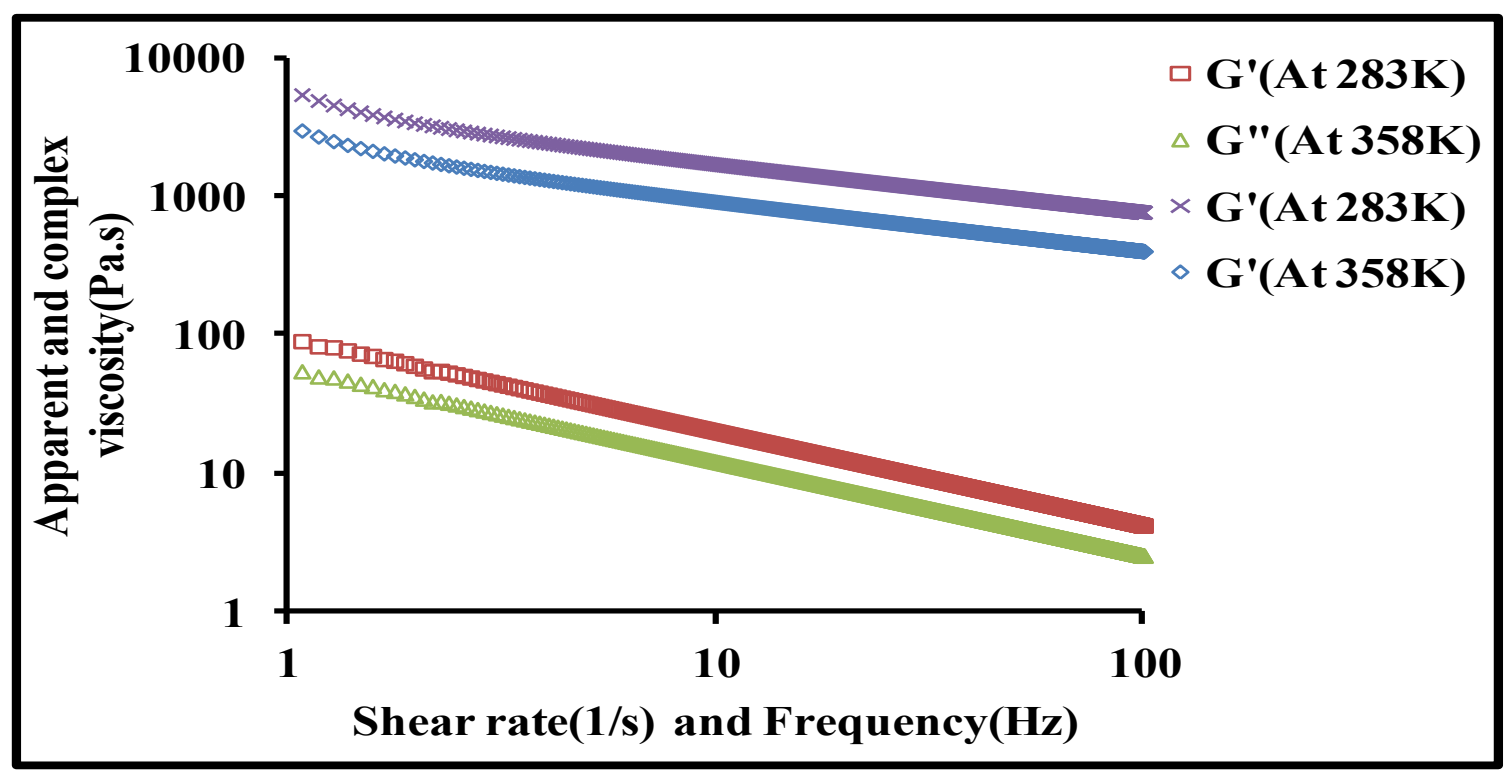

Figure 5. Complex viscosity as a function of oscillatory frequency and apparent viscosity as a function of shear rate of Gongura leaves puree at 283 and $358 \mathrm{~K}$.

\section{Conclusions}

The current finding has assessed the density of a GL puree as a component of temperature and TSS. The increment in TSS and decrement in temperature brings about density increment. With respect to all scope of temperatures, density was observed to be emphatically influenced by puree TSS. GL puree demonstrates shear-thinning conduct and found to display HB flow behavior with yield stress decrease with increment in temperature (diminish from 59.245 to $16.851 \mathrm{~Pa}$, was seen as the temperature was raised from $283-358$ $\mathrm{K})$. $\mathrm{K}$ value of puree lessens from 35.94746 to 17.72813 $\mathrm{Pa} \mathrm{s}^{\mathrm{n}}$ and $\mathrm{n}$ was found to change from 0.39898 to 0.45893 as the temperature was raised from 283 to $358 \mathrm{~K}$. The GL puree viscoelastic conduct was described as a weak gel and in oscillatory frequency, its $\mathrm{G}^{\prime}$ and $\mathrm{G}^{\prime \prime}$ was portrayed by utilizing a power function. A power modified Cox-Merz $\mathrm{s}$ was shown that the puree rheological properties could be coordinated by either oscillatory or steady-state shear tests. The information obtained is conceivably helpful for future examinations on the properties of food and process design.

\section{References}

Aguado, M. A., Ibarz, A. (1988). Variación de la densidad de un zumo de manzana con la temperatura y concentración. Alimentacion, Equipos y Tecnologia, 3, 209-216.

Ahmed, J., Al-Salman, F., Almusallam, A. S. (2013). Effect of blanching on thermal color degradation kinetics and rheological behavior of rocket (Eruca sativa) puree. Journal of Food Engineering, 119(3), 660667.

Alvarez, M. D., Canet, W. (2013). Timeindependent and time-dependent rheological characterization of vegetablebased infant purees. Journal of Food Engineering, 114(4), 449-464.

Ahmed, J., Ramaswamy, H. S. (2006). Viscoelastic and thermal characteristics of vegetable puree-based baby foods. Journal of Food Process Engineering, 29(3), 219233.

Ahmed, J., Ramaswamy, H. S. (2006). Viscoelastic properties of sweet potato puree infant food. Journal of Food Engineering, 74(3), 376-382.

Ahmed, J., Ramaswamy, H. S. (2007). Dynamic and steady shear rheology of fruit puree based baby foods. Journal of Food 
Science and Technology-Mysore-, 44(6), 579.

Ahmed, J., Ramaswamy, H. S., Sashidhar, K. C. (2007). Rheological characteristics of tamarind (Tamarindus indica L.) juice concentrates. LWT-Food Science and Technology, 40(2), 225-231.

Alvarado, J. D. D., Romero, C. H. (1989). Physical properties of fruits I. density and viscosity of juices as functions of soluble solids content and temperature. Latin American Applied Research, 19(15), 15-21.

Alvarez, M. D., Fernández, C., Canet, W. (2004). Rheological behavior of fresh and frozen potato puree in steady and dynamic shear at different temperatures. European Food Research and Technology, 218(6), 544-553.

Arnon, D. (1949). Estimation of Total chlorophyll. Plant Physiology, 24(1), 1-15.

Augusto, P. E., Falguera, V., Cristianini, M., Ibarz, A. (2011). Influence of fiber addition on the rheological properties of peach juice. International Journal of Food Science \& Technology, 46(5), 1086-1092.

Augusto, P. E., Falguera, V., Cristianini, M., Ibarz, A. (2011). Viscoelastic properties of tomato juice. Procedia Food Science, 1, 589-593.

Balaghi, S., Mohammadifar, M. A., Zargaraan, A., Gavlighi, H. A., Mohammadi, M. (2011). Compositional analysis and rheological characterization of gum tragacanth exudates from six species of Iranian Astragalus. Food Hydrocolloids, 25(7), 1775-1784.

Bayod, E., Månsson, P., Innings, F., Bergenståhl, B., Tornberg, E. (2007). Low shear rheology of concentrated tomato products. Effect of particle size and time. Food Biophysics, 2(4), 146-157.

Bistany, K. L., Kokini, J. L. (1983). Dynamic viscoelastic properties of foods in texture control. Journal of Rheology, 27(6), 605620.

Campo-Deaño, L., Tovar, C. (2009). The effect of egg albumen on the viscoelasticity of crab sticks made from Alaska Pollock and
Pacific Whiting surimi. Food Hydrocolloids, 23(7), 1641-1646.

Canet, W., Álvarez, M. D., Fernández, C., Luna, P. (2005). Comparisons of methods for measuring yield stresses in potato puree: effect of temperature and freezing. Journal of Food Engineering, 68(2), 143153.

Cepeda, E., Villaran, M. C. (1999). Density and viscosity of Malus floribunda juice as a function of concentration and temperature. Journal of Food Engineering, 41(2), 103107.

Colin-Henrion, M., Cuvelier, G., Renard, C. M. G. C. (2007). Texture of pureed fruit and vegetable foods. Stewart Postharvest Review, 5, 1-14.

Constenla, D. T., Lozano, J. E., Crapiste, G. H. (1989). Thermophysical properties of clarified apple juice as a function of concentration and temperature. Journal of Food Science, 54(3), 663-668.

Cox, W. P., Merz, E. H. (1958). Correlation of dynamic and steady flow viscosities. Journal of Polymer Science, 28(118), 619622.

Da Silva, J. A. L., Rao, M. A. (1992). Viscoelastic Properties of Food Hydrocolloid Dispersions en Rao MA. Steffe, JF.(Eds.) Viscoelastic Properties of Foods 285-315.

Espinosa, L., To, N., Symoneaux, R., Renard, C. M., Biau, N., \& Cuvelier, G. (2011). Effect of processing on rheological, structural and sensory properties of apple puree. Procedia Food Science, 1, 513-520.

Gunasekaran, S., Ak, M. M. (2000). Dynamic oscillatory shear testing of foods-selected applications. Trends in Food Science \& Technology, 11(3), 115-127.

Hajieghrary, F., Homayouni-Rad, A. (2016). Physical, rheological and sensory properties of non-alcoholic malt beverage formulated with date syrup. Carpathian Journal of Food Science \& Technology, 8(4).

Haminiuk, C. W. I., Sierakowski, M. R., Maciel, G. M., Vidal, J. R. M. B., Branco, I. G., Masson, M. L. (2006). Rheological 
properties of butia pulp. International Journal of Food Engineering, 2(1)

Ibarz, A., Miguelsanz, R. (1989). Variation with temperature and soluble solids concentration of the density of a depectinised and clarified pear juice. Journal of Food Engineering, 10(4), 319323.

Ice, J.R., Hamann, D.D., Purcell, A.E. (1980). Effects of $\mathrm{pH}$, enzymes, and storage time on the rheology of sweet potato puree. Journal of Food Science, 45(6), 1614-1618.

Işıklı, N. D., Karababa, E. (2005). Rheological characterization of fenugreek paste (çemen). Journal of Food Engineering, 69(2), 185-190.

Karuna, D., Noel, G., Dilip, K. (1996). Food and nutrition bulletin, 17: 2. United Nation University.

Koocheki, A., Razavi, S. M. A., Milani, E., Moghadam, T. M., Abedini, M., Alamatiyan, S., Izadkhah, S. (2007). Physical properties of watermelon seed as a function of moisture content and variety. International Agrophysics, 21(4), 349.

Kumar, S., Kumar, P. (2015). Rheological modeling of non-depectinized beetroot juice concentrates. Journal of Food Measurement and Characterization, 9(4), 487-494.

Manohar, B., Ramakrishna, P., Udayasankar, K. (1991). Some physical properties of tamarind (Tamarindus indica L.) juice concentrates. Journal of Food Engineering, 13(4), 241-258.

Massa, A., González, C., Maestro, A., Labanda, J., Ibarz, A. (2010). Rheological characterization of peach purees. Journal of texture studies, 41(4), 532-548.

Nindo, C. I., Tang, J., Powers, J. R., Bolland, K. (2004). Energy consumption during Refractance Window ${ }^{\circledR}$ evaporation of selected berry juices. International Journal of Energy Research, 28(12), 1089-1100.

Pourmohammadi, K., Najafi, M. B., Majzoobi, M., Koocheki, A., Farahnaki, A. (2017). Evaluation of dough rheology and quality of sugar-free biscuits: isomalt, maltodextrin, and stevia. Carpathian Journal of Food Science \& Technology, 9(4).

Puro, K., Sunjukta, R., Samir, S., Ghatak, S., Shakuntala, I., Sen, A. (2014). Medicinal uses of Roselle plant (Hibiscus sabdariffa L.): a mini review. Indian Journal of Hill Farming, 27(1), 81-90.

Rao, M. A. (2014). Flow and functional models for rheological properties of fluid foods. In Rheology of fluid, semisolid, and solid foods (pp. 27-61). Springer, Boston, MA.

Rao, M. A., Rizvi, S. S., Datta, A. K., \& Ahmed, J. (2014). Engineering properties of foods. CRC press.

Rudra, S. G., Sarkar, B. C., Shivhare, U. S., Basu, S. (2008). Rheological properties of coriander and mint leaf puree. Journal of food process engineering, 31(1), 91-104.

Steffe, J. F. (1996). Rheological methods in food process engineering. Freeman press.

Sun, A., Gunasekaran, S. (2009). Yield stress in foods: measurements and applications. International Journal of Food Properties, 12(1), 70-101.

Tabilo-Munizaga, G., Barbosa-Cánovas, G. V. (2005). Rheology for the food industry. Journal of food engineering, 67(1-2), 147156.

Zuritz, C. A., Puntes, E. M., Mathey, H. H., Pérez, E. H., Gascón, A., Rubio, L. A., Cabeza, M. S. (2005). Density, viscosity, and coefficient of thermal expansion of clear grape juice at different soluble solid concentrations and temperatures. Journal of Food Engineering, 71(2), 143-149. 